\title{
KELAN TYÖKYVYTTÖMYYSELÄKKEIDEN HYLKÄYKSET
}

\section{Mitkä syyt ovat yhteydessä hylkäyksiin ja hylkäysosuuksien vaihteluun vakuutuspiireittäin?}

Kelan työkyvyttömyyseläkkeiden hylkäysosuudet ovat viime vuosina koko ajan pikkuhiljaa kasvaneet. Hylkäysosuudet myös vaihtelevat vakuutuspiireittäin. Tein lisensiaattitutkielmani Kelan työkyvyttömyyseläkkeiden hylkäyksistä ja niiden vakuutuspiirikohtaisesta vaihtelusta. Aineistona minulla olivat kaikki vuoden 2014 aikana Kelalta uuden työkyvyttömyyseläkepäätöksen saaneet henkilöt. Hylkäysosuuksien vaihtelu oli tuolloin voimassa olevan vakuutuspiirijaon mukaisesti Pohjois-Karjalan 35 prosentista Keski-Uudenmaan 44 prosenttiin. Tutkimukseni oli kvalitatiivinen rekisteritutkimus, ja varsinaisena tutkimusmenetelmänä oli logistinen regressioanalyysi.

Hylkäysten määrän vähentämisessä on keskeistä se, että niin sanotut turhat hakemukset saataisiin estettyä jo ennalta. Osa hylätyistä työkyvyttömyyseläkehakemuksista johtaa lisäksi muutoksenhakuun, joka sitoo eri toimijoiden työpanosta jopa enemmän kuin varsinainen hakemuskäsittely. Muutoksenhakuasteessa kuitenkin vain 7 prosenttia hakemuksista johtaa päätöksen muuttamiseen (SOMLA 2015). Työkyvyttömyyseläkkeiden hylkäykset eivät ole pelkästään taloudellinen asia, vaan niihin liittyy hyvin vahvasti myös sosiaalinen ja oikeusturvanäkökulma. Työkyvyttömyyseläkehakemuksen hylkäämisen kokee tilasto- jen mukaan vuosittain noin 6000 työeläkelaitoksen kautta eläkettä hakenutta ja noin 7800 Kelan kautta eläkettä hakenutta (Eläketurvakeskus 2015, Kela 2015). Hylkäys voi aiheuttaa hakijalle vaikean tilanteen ja johtaa pitkään valituskierteeseen ja toimeentulon epävarmuuteen (Honkanen 2014, 157). Henkilökohtaisella tasolla työkyvyttömyyseläkkeen hylkääminen voi aiheuttaa hakijalle myös pois käännyttämistä, jolloin avuntarvitsija suljetaan hänen tarvitsemansa avun ulkopuolelle (Hänninen \&t Karjalainen 2007, 9, 170).

\section{Hakijan oma tilanne selittää hylkäyksiä}

Työkyvyttömyyseläkkeen hakijoihin liittyvät yksilölliset tekijät selittävät pääosin hylkäyksiä ja hylkäysosuuksien vakuutuspiirikohtaista vaihtelua. Sukupuolten suhteen ei ollut eroa hylkäysosuuksissa, vaan naisten ja miesten hakemuksia hylättiin lähes yhtä paljon. Niin sanotussa parhaassa työiässä olevien hakemuksia hylättiin kolminkertaisesti verrattuna nuorimpaan ikäryhmään. Kaikkein vanhimman (yli 60-vuotiaiden) ja nuorimman (alle 25-vuotiaiden) ikäryhmän hakemuksia hylättiin kaikkein vähiten. Nuorimman ikäluokan osalta on huomioitava kuitenkin se, että tässä ryhmässä olivat myös kehitysvammaisuuden vuoksi työkyvyttömyyseläkettä saaneet. Tuloksista voisi yleistäen todeta, että suurissa opiskelijakaupungeissa nuoret ha- 
keutuvat työkyvyttömyyseläkkeelle mielenterveyden häiriöiden vuoksi ja Itä- ja PohjoisSuomessa vastaavasti iäkkäät henkilöt tuki-ja liikuntaelinsairauksien vuoksi, mikä heijastuu myös hylkäysten osuuksiin. Sairausluokista vähiten hylättiin kasvainten vuoksi tehtyjä eläkehakemuksia, joissa hylkäysosuus on vain 11 prosenttia, ja eniten tuki- ja liikuntaelinsairauksien vuoksi tehtyjä eläkehakemuksia, joissa hylkäysosuus on 53 prosenttia.

Pitkään (yli 200 päivää) työttöminä olleiden henkilöiden työkyvyttömyyseläkehakemusten hylkäysriski oli lähes kaksikymmenkertainen verrattuna niihin, joilla ei ollut lainkaan maksussa työttömyysturvaa vuosina 2013 ja 2014. Pitkäaikaistyöttömien hakemuksista hylättiin kaikkiaan lähes 90 prosenttia. Työttömien hakemuksia hylätään muita useammin todennäköisesti siksi, että heillä ei ole työterveyshuollon kaltaista toimijaa ohjaamassa kuntoutukseen tai koordinoimassa heidän kokonaistilannettaan (Kivekäs 2013). Lisäksi työttömien työkyvyn arvioinnissa on omat haasteensa, koska heidän työssä olostaan on voinut kulua jo hyvinkin pitkä aika eikä enää ole ehkä lainkaan tarjolla sellaista työtä, josta he ovat jääneet työttömiksi.

Hylkäävän työkyvyttömyyseläkepäätöksen saavan työttömän profiilissa näyttäytyvät sairauspäivärahakauden katkonaisuus, hoitavan lääkärin lausuntojen osittaiset puutteet, kuntoutumista ehkäisevä päihteiden käyttö, työeläkekuntoutukseen ohjaamattomuus ja asiakkaan kokonaistilanteen koordinoinnin puute (Kivekäs ym. 2013, 48). Työttömien terveysongelmat eivät välttämättä myöskään ole viranomaisten tiedossa, koska heidän sairastaessaan heille ei ole aina kirjoitettu sairauslomaa (Honkanen 2014, 156). Tässä tarvittaisiinkin lisää moniammatillista tai monikerroksellista (Hupe \&t Hill 2007) katutason byrokratiatyötä, jota eri paikalliset toimijat tekevät keskenään asiakkaiden asioita edistäessään.

Niillä työkyvyttömyyseläkkeen hakijoilla, jotka eivät ole olleet lainkaan työttöminä, hylkäysten osuus on selvästi pienempi. Tulos tukee aiemmissa tutkimuksissa esiin noussutta ilmiötä, jossa työttömyyden lisääntyessä myös niin sanotut turhat hakemukset lisääntyvät
(Gould ym. 2012). Työttömyyden pitkittyessä työkyvyttömyyseläke voi olla houkutteleva poistumistie työelämästä (Blomgren \&t Virta 2012, 29). Eli vaihtoehdoksi työttömyydelle haetaan työkyvyttömyyseläkettä, vaikka edellytyksiä työkyvyttömyyseläkkeen myöntämiselle ei olisikaan olemassa. Tämän hakijaryhmän osalta hylkäävä päätös on todennäköisesti myös raskas poiskäännyttämiskokemus, koska hakijat voivat joutua väliinputoajiksi eri etuuksien väliin: he ovat liian terveitä työkyvyttömyyseläkkeelle mutta liian sairaita töihin (Honkanen 2014). Työttömän hakijan ohjaaminen kuntoutukseen tai koulutukseen työkyvyttömyyseläkkeen sijaan voidaan myös nähdä poiskäännyttämisenä, mutta tämän poiskäännyttämisen voidaan katsoa olevan hakijalle hyödyksi (Hänninen \& Karjalainen 2007). Myös täyden sairauspäivärahakauden täyttyminen näyttäisi lisäävän hieman hylkäyksen riskiä. Suurella joukolla työkyvyttömyyseläkkeelle siirtyvistä ei ole ollut mitenkään merkittävää sairauspäivärahahistoriaa (Laaksonen ym. 2014, 50).

\section{Työkykyneuvontaan osallistuminen ei vähennä hylkäysriskiä}

Työkykyneuvonnalla on nähty olevan selvä tilaus etenkin työttöminä oleville asiakkaille (Kivekäs 2013, Hiljanen ym. 2013). Kuitenkin myös työkykyneuvontaan osallistuminen näyttäisi tutkimukseni valossa altistavan hylkäyksille: tämän ryhmän riski hylkäyksille on yli puolitoistakertainen verrattuna niihin, jotka eivät ole olleet työkykyneuvonnassa. Työkykyneuvontaan osallistuneiden joukossa oli työttömiä selvästi enemmän ja heidän työttömyytensä oli kestänyt pitemmän aikaa kuin hakijoiden keskimäärin. Heistä valtaosa oli jo ikääntyneitä, ja sairausperusteena oli useimmiten tuki- ja liikuntaelinsairaudet. Toisaalta on huomattava se seikka, että Pohjois-Karjalan vakuutuspiirissä joka neljäs työkyvyttömyyseläkettä hakenut oli ollut työkykyneuvonnassa, ja siitä huolimatta Pohjois-Karjalan työkyvyttömyyseläkkeiden hylkäysosuus oli valtakunnan alhaisin.

Joka tapauksessa tällä tutkimuksella jou- 
dutaan ainakin osittain kumoamaan näkemys, jonka mukaan työkykyneuvontaa lisäämällä ja tehostamalla voidaan vähentää työkyvyttömyyseläkehylkäyksiä luontevalla tavalla, kun "asiakas pääsee kuntoutukseen tai tilalle löytyy ajoissa jokin muu ratkaisu eikä todennäköisesti hylkäämiseen johtavaa eläkehakemusta koskaan tehdäkään” (Kivekäs 2013). Tässä rekisteritutkimuksessa lähes 60 prosenttia työkykyneuvontaan osallistuneiden hakemuksista hylättiin, joten siltä osin Kivekkään esittämä näkemys ei vahvistunut. Vai voisiko syynä olla se, että työkykyneuvontaa ei vieläkään tehdä riittävän laajasti ja vaikuttavasti? Tai voisiko olla niin, että ilman työkykyneuvontaa hylkäysosuudet olisivat vieläkin korkeammat?

\section{Vakuutuspiirien kesken on eroja}

Vakuutuspiirien alueelta tulevien työkyvyttömyyshakemusten hakutiheys vaihtelee maan eri osissa siten, että se on Espoon vajaasta 3 promillesta Lapin 8 promilleen. Tutkimuksessa havaittiin, että hakutiheyden noustessa hylkäysriski vastaavasti kasvoi, joten tämä vahvisti aikaisempaa näkemystä siitä, että korkea hakemusmäärä altistaa keskimääräistä suuremmalle hylkäysosuudelle (Blomgren \& Virta 2012). Samoin työttömyysasteiden ääripäät olivat kaukana toisistaan, kun Pohjanmaalla työttömyysaste oli vajaat 8 prosenttia ja Pohjois-Karjalassa vajaat 18 prosenttia. Alueen työttömyysaste ei kuitenkaan selittänyt hylkäyksiä yhtä suoraviivaisesti kuin hakijoiden henkilökohtainen työttömyys: matalan työttömyysasteen vakuutuspiireissä oli korkeitakin hylkäysosuuksia, ja taas päinvastoin korkeimman työttömyyden vakuutuspiirissä työkyvyttömyyseläkkeiden hylkäysosuus oli kaikkein pienin. Tämä tulos poikkeaa työeläkejärjestelmän puolella tehdystä tutkimuksesta, jonka mukaan todennäköisyys työkyvyttömyyseläkkeelle hakeutumisessa kasvaa alueen työttömyyden kasvaessa (Laaksonen \&t Gould 2013a ja 2013b).

Vakuutuspiirikohtaisesti on havaittavissa eroja myös eri sairausluokkien hylkäysosuuksissa. Suurimmat erot löytyivät verenkierto- elinten sairauksien perusteella tapahtuvissa hylkäyksissä. Näitä hylättiin vähiten LänsiUudellamaalla, jossa hylkäysosuus oli vain 6 prosenttia. Sen sijaan Keski-Suomessa tässä ryhmässä hylkäysosuus oli lähes 37 prosenttia. Tässä yhteydessä herää kysymys, voisiko alueen terveydenhuollon toiminnalla ja/ tai eri toimijoiden yhteistyöllä olla yhteyttä näin suuriin hylkäyseroihin. Tämä tulos on mielenkiintoinen ja olisikin tarkemman tutkimisen arvoinen.

Merkittäviä eroja havaittiin vakuutuspiirien välillä myös kuntoutukseen osallistumisessa. Oulussa hakijoista oli ollut kuntoutuksessa yli 16 prosenttia ja vastaavasti Kymenlaaksossa vain runsas 5 prosenttia. Näin suuret erot eivät todennäköisesti ole selitettävissä väestön yksilöllisillä ominaisuuksilla, vaan eri vakuutuspiirien alueella on saattanut olla erilaista käytäntöä kuntoutustoimenpiteisiin ohjaamisessa. Tutkimuksella ei pystytä antamaan vastausta siihen, mistä tämä ero johtuu.

Merkittäviä eroja on myös kuntoutukseen osallistuneiden henkilöiden hakemusten hylkäysosuuksissa. Espoossa kuntoutukseen osallistuneiden työkyvyttömyyseläkehakemuksia on hylätty 36 prosenttia, kun Varsinais-Suomessa kuntoutukseen osallistuneiden hakemuksista on hylätty lähes kaksinkertainen määrä eli 61 prosenttia. Näin mittava ero hylkäysosuuksissa nostaa esille kysymyksen siitä, onko kuntoutukseen ohjaaminen tapahtunut kaikissa vakuutuspiireissä samoilla kriteereillä, vai onko tässä havaittavissa organisaatiokohtaista portinvartijuutta, jossa etuuden ratkaisijat voivat omalla toiminnallaan myös vaikuttaa organisaation toimintaan (Shoemaker \&t Vos 2009, 62) eli tässä tapauksessa työkyvyttömyyseläkkeiden hylkäämiseen. Tällä tutkimuksella ei voida kuitenkaan tarkemmin selvittää, mitkä seikat tässä ovat olleet taustalla, mutta tulos näyttäytyy viranomaisen harkintavallan erilaisena käyttönä eri vakuutuspiireissä.

Vastaavaa vaihtelua vakuutuspiirien välillä on nähtävissä myös täyden sairauspäivärahakauden jälkeen hylätyissä hakemuksissa. Oulussa täyden sairauspäivärahakauden jälkeen työkyvyttömyyseläkettä hakeneiden ha- 
kemuksista hylättiin 61 prosenttia, kun KantaHämeessä hylkäysten osuus oli vain vajaat 38 prosenttia. Kun erot hylkäysosuuksissa ovat näin suuret, voidaan tässäkin kysyä, ovatko ilmiön taustalla Oulun ja Kanta-Hämeen toisistaan poikkeavat sairauspäivärahan myöntökäytännöt (eli viranomaisen harkintavallan erilainen käyttö) vai voidaanko eroja selittää ainoastaan väestön yksilöllisten ominaisuuksien vaihtelulla.

Kun tarkastellaan vakuutuspiirin toimintaa työkykyneuvontaan poimittujen ja sidosryhmäyhteisyön laajuuden mukaan, vakuutuspiirikohtaista vaihtelua on jälleen hyvin paljon. Näissä molemmissa ääripäät olivat todella kaukana toisistaan, kun Päijät-Hämeessä työkykyneuvontaan oli poimittu vain 6 prosenttia hakijoista ja Pohjois-Karjalassa lähes 27 prosenttia. Yhtä huomattavat erot olivat myös sidosryhmäyhteistyöhön käytettyjen päivien määrässä: Oulussa tähän oli panostettu 0,03 päivää ja Pohjois-Karjalassa 2,23 päivää 1000 asukasta kohti. Eri vakuutuspiirien toiminta näyttäytyy hyvinkin erilaisena, ja tämä kuvastaa niitä valintoja, joita vakuutuspiireissä on tehty. Vakuutuspiirien työkykyneuvontaan poimittujen määrä ja tehdyn sidosryhmäyhteistyön määrä ovat siis yhteydessä hylkäysosuuksiin, mutta regressioanalyysissä saatu tulos ei ollut tilastollisesti merkitsevä. Kuitenkin vakuutuspiirin tekemällä sidosryhmäyhteistyön määrällä silloin, kun yhteistyötä on tehty paljon, näyttää olevan yhteyttä vähäisempiin työkyvyttömyyseläkkeiden hylkäyksiin. Tästä voisi päätellä, että vakuutuspiirin aktiivisuudella verkostoitua ja toimia yhteistyössä paikallisten toimijoiden kanssa voidaan saada hylkäysosuuksia alhaisemmiksi. Tässä näyttäytyy kelalaisten toimijoiden rooli aktiivisina katutason byrokraatteina, jotka käyttävät itsenäisesti harkintavaltaa mutta toimivat myös yhteistyössä eri organisaatioiden kollegoiden kanssa (Lipsky 1980).

\section{Johtopäätökset}

Nykyisin työvoiman palvelukeskusten ja kuntien työllistämisyksiköiden toiminnan ulkopuolelle jää työttömiä, jotka hakevat työ- kyvyttömyyseläkettä omatoimisesti ja ilman viranomaisten tai terveydenhuollon tukea. Ruotsalaistutkimuksessa on todettu, että sosiaalivakuutuksen toimijoiden aloitteesta tai ohjauksessa tehdyt hakemukset saavat myönteisen päätöksen selvästi useammin kuin ilman heidän apuaan tehdyt hakemukset (Ydreborg \&t Ekberg 2004). Kelassa kannattaisi ehkä pohtia, voisiko työkyvyttömyyseläkeprosessia muuttaa siten, että hakijat ohjattaisiin (tai velvoitettaisiin) hakeutumaan joko ohjauskäynnille tai puhelinohjaukseen vakuutuspiirin etuuskäsittelijälle tai työkykyneuvojalle (tai moniammatillista ohjausta tarvitsevien työttömien kohdalla työvoiman palvelukeskukseen) ennen hakemuksen jättämistä, mikäli työterveyshuolto ei ole ollut mukana hakemusprosessissa. Mikäli hakija saisi tukea ennen hakemuksen jättämistä, häntä voitaisiin ohjata jo siinä vaiheessa täydentämään mahdollisesti puutteellista hakemustaan tai hänet voitaisiin tarvittaessa ohjata esimerkiksi kuntoutustoimien pariin.

Toisena vaihtoehtona olisi kontaktoida hakijaa henkilökohtaisesti välittömästi sen jälkeen, kun hakemus on saapunut Kelaan, jo ennen kuin hakemusta ryhdytään tarkemmin käsittelemään. Tämä ei kuitenkaan poistaisi niin sanottuja turhia hakemuksia yhtä tehokkaasti kuin hakijan ja viranomaisen yhteistyö ennen hakemuksen jättämistä. Lisäksi yhtenä vaihtoehtona on jo aiemmin esille noussut ehdotus, että hakijoita kuultaisiin siinä vaiheessa, kun kielteinen päätös näyttäisi olevan tulossa (Paunio 2002, 24). Sekin olisi hakijaa ajatellen myönteinen asia, mutta mielestäni asiakkaan kuuleminen tässä vaiheessa on myöhäistä, koska kielteinen päätös on käytännössä jo tehty ja etuuden ulkopuolelle jääminen on tosiasia. Kuuleminen voisi kyllä osaltaan auttaa hakijaa ymmärtämään hylkäyksen taustalla olevia tekijöitä ja näin ehkä vähentää muutoksenhakujen määrää, mutta hakijan poiskäännyttämisen kokemukseen se ei välttämättä auta.

Yhtenä vaihtoehtona voisi olla myös Kelan etuuskäsittelyn uudistaminen nykyisestä etuuteen pohjautuvasta siiloutuneesta mallista siten, että sairauspäivärahan, kuntoutuk- 
sen ja työkyvyttömyyseläkkeiden hakemusten käsittelijät tekisivät yhä enemmän kokonaisvaltaista etuustyötä kaikki etuudet huomioiden ja asiakkaiden tarpeista lähtien. Nykyisessä mallissa voidaan nähdä katutason byrokraattien jopa liika erikoistuminen, joka estää heitä näkemästä työtään (asiakkaan tilannetta) kokonaisuutena. Ratkaisujen tekeminen voi olla tällöin kapeakatseista portinvartijuutta (Lipsky 1980). Mikäli etuuskäsittelyn katsantokannan laajentaminen ei ole mahdollista, ainakin etuuskäsittelijöiden tietämystä eri etuuksista tulisi lisätä samoin kuin yhteistyötä toisen etuuden työntekijöiden kanssa. Samalla tämä tarkoittaisi muutosta myös asiantuntijalääkäreiden toimintaan. Heidän tulisi jo sairauspäivärahakauden aikaista lausuntoa laatiessaan pohtia nykyistä laajemmin hakijan tulevaa työkykyä. Tällä toiminnalla saataisiin nykyistä varhaisemmassa vaiheessa hakijat ohjattua kuntoutustoimenpiteisiin, jolloin mahdollinen kuntoutus päästäisiin aloittamaan riittävän ajoissa.

Se, että eri vakuutuspiireissä työkykyneuvontaan näyttää ohjautuvan hakijoita hyvin vaihtelevasti, kuvastaa vakuutuspiirien toimintaa, mutta se kuvastaa samalla myös sitä, mitä valintoja vakuutuspiireissä on tehty esimerkiksi eri tehtävien priorisoinnissa. Jos vakuutuspiirien toimintaa tarkastellaan portinvartijuuden kautta, voidaan kysyä, missä määrin työkykyneuvojat ja sairauspäivärahan etuuskäsittelijät toimivat tässä itsenäisesti portinvartijoina ja missä määrin heidän toimintaansa ohjaavat organisaation arvot, käytännöt tai esimiesten omat henkilökohtaiset näkemykset (Shoemaker \&t Vos 2009). Voidaan myös kysyä, missä määrin etuuskäsittelijöille osoitetaan aikaa tähän työhön ja minkälaista toimintaa heiltä edellytetään. Kun työkyvyttömyyseläkkeiden osalta on todettu hylkäyksen olevan hakijalle poiskäännyttämistä, voidaanko poiskäännyttämistä nähdä myös siinä, että työkykyneuvontaan ohjataan joissakin paikoin vain hyvin pieni määrä hakijoista. Joka tapauksessa yhteistä näkemystä tai toimintatapaa asiassa ei ole vakuutuspiireille muodostunut tai Kelan linjausta on tulkittu eri vakuutuspiireissä eri tavoin, jolloin myös resurssien kohdistaminen on priorisoitu eri tavoin. Tässä olisikin nähtävissä Kelan etuusyksikössä yhteisen keskustelun ja arvioinnin tarvetta.

Kansalaisten luottamus koko työkyvyttömyyseläkejärjestelmään on horjunut (Paunio 2002, 24), ja epäoikeudenmukaisiksi koetut etuushylkäykset ruokkivat epäluottamusta, vaikka hylkäyksiin olisikin perusteltu syy. Sen vuoksi eri toimijoiden tulisi tehdä kaikki voitava, että luottamusta viranomaisten toimintaan saataisiin vahvistettua. Yhtenä keinona on se, että asiakkaat saadaan ohjattua yhteistyössä sujuvasti ja oikea-aikaisesti tarvitsemiinsa palveluihin.

Tulosten merkitys: Tutkimuksen tuloksia voidaan soveltaa käytäntöön kaikissa niissä tilanteissa ja kohtaamisissa, joissa etenkin jo pitempään työttöminä olleiden ohjaamista ja neuvontaa tapahtuu. Myös työkyvyttömyyseläkeneuvontaa antavat voivat soveltaa tuloksia työssään. Vakuutuspiirien toiminnassa tuloksia voidaan hyödyntää toiminnan yhdenmukaistamisessa ja kehittämisessä.

Avainsanat: työkyvyttömyyseläke, hylkäysosuus, hylkäysriski, etuuskäsittely, työkykyneuvonta, vakuutuspiirikohtainen vaihtelu, harkintavallan käyttö, katutason byrokratia, portinvartijuus, poiskäännyttäminen

\section{Riitta Huurinainen, KM, hyvinvointijohtaja, Joensuun kaupunki \\ (vakuutuspiirin johtaja, Kela, 28.2.2017 saakka)}

\section{Lähteet}

Blomgren J, Virta L (2012) Kansaneläkejärjestelmän työkyvyttömyyseläkkeiden hylkäyksen vuosina 2005-2011. Nettityöpapereita 39. Kela, Helsinki.

Gould R, Saarnio L, Härkäpää K (2012) Myöntö vai hylkäys. Teoksessa Gould R, Härkäpää K,

Järvikoski A (toim.) Toimiiko työeläkekuntoutus? Eläketurvakeskuksen tutkimuksia 1. Eläketurvakeskus, Helsinki.

Eläketurvakeskus (2015) Työeläkejärjestelmästä myönnettyjen uusien työkyvyttömyyseläkkeiden ratkaisut vuosina 2005-2014. 
Hiljanen I, Kantonen P, Kivekäs J (2013) Polku hylkäävään työkyvyttömyyseläkepäätökseen. Kansaneläkelaitoksen ja keskinäinen työeläkeyhtiö Varman selvitys. Kela, Helsinki.

Honkanen P (2014) Työkyvyttömyyseläkehakemusten hylkäyspäätökset sosiaalisena ja oikeudenmukaisuuskysymyksenä. Teoksessa Kalliomaa-Puha L, Kotkas T, Rajavaara M (toim.) Harkittua? Avauksia sosiaaliturvan harkintavallan tutkimukseen. Teemakirja 13. Kelan tutkimusosasto, Helsinki. 156-181.

Hupe P, Hill M (2007) Street-level Bureaucracy and Public Accountability. Public Administration 85, 2, 279-299.

Hänninen S, Karjalainen J (2007) Tarve harkinnassa. Teoksessa Hänninen S, Karjalainen J, Lehtelä K-M (toim.) Pääsy kielletty, poiskäännyttämisen politiikka ja sosiaalityö. Stakes, Helsinki.

Kela (2015) Varsinaisen työkyvyttömyyseläkkeen hakemuksen hylkäysprosentit vuonna 2014. Kelaston raportti WIT107A.

Kivekäs J (2013) Työkyvyttömyyseläkkeiden viidakossa hylkäyksiä voitaisiin vähentää. Varman blogi 11.10.2013. https://www.varma.fi/fi/ajankohtaista/blogi/blogiarkisto/pages/tyokyvyttomyyselakkeiden-viidakossa-hylkayspaatoksia-voitaisiinvahentaa.aspx. Viitattu 31.1.2015.

Kivekäs J, Hiljanen I, Kantonen P (2013) Polku hylkäävään työkyvyttömyyseläkepäätökseen. Kuntoutus 2, 45-49.

Laaksonen M, Blomgren J, Gould R (2014) Työkyvyttömyyseläkkeelle siirtyneiden sairauspäiväraha-, kuntoutus- ja työttömyyshistoria. Eläketurvakeskuksen raportteja 05. Helsinki, Eläketurvakeskus.

Laaksonen M, Gould R (2013a) The effect of municipality characteristics on disability retirement. European Journal of Public Health 24, 1, 116-121.

Laaksonen M, Gould R (2013b) Regional differences in disability retirement: explaining between-county differences in Finland. Scandinavian Journal of Work, Environment and Health 39, 6, 609-617.

Lipsky M (1980) Street-lewel Bureaucracy, Dilemmas of the Individual in Public Services. New York, Russel Sage Foundation.

Paunio R-L (2002) Toimeentuloturvajärjestelmän kehittämistarpeita. Julkaisussa Eduskunnan oikeusasiamiehen kertomus toiminnastaan vuonna 2001. Helsinki, Eduskunnan oikeusasiamiehen kanslia.

Shoemaker PJ, Vos TP (2009) Gatekeeping Theory. New York, Routledge.

SOMLA (2015) Sosiaaliturvan muutoksenhakulautakunnan ratkaisutilasto. http://www.sosiaaliturvanmuutoksenhakulautakunta.fi/files/ratkaisuti- lasto_2015.pdf. Viitattu 18.6.2016.

Ydreborg BA-M, Ekberg K (2004) Disqualified for disability pension - a case/referent study. Disability and Rehabilitation 26, 1079-1086. 